\title{
RENAL FUNCTION AS A FACTOR IN FLUID RETENTION IN PATIENTS WITH CIRRHOSIS OF THE LIVER ${ }^{1}$
}

\author{
By STEPHEN H. LESLIE, BARBARA JOHNSTON, AND ELAINE P. RALLI
}

\author{
(From The Department of Medicine, New York University College of Medicine, and the Third \\ [N.Y.U.] Medical Division, Bellerue Hospital, New York, N. Y.)
}

(Submitted for publication May 25, 1951; accepted August 13, 1951)

\section{INTRODUCTION}

The diminished rate of urine excretion, which has been observed in association with severe liver damage, is one indication of the disturbance of water balance occurring in patients with liver disease $(1,2)$. Not only is the 24 hour urine output decreased, but the response to the water tolerance test is also distinctly abnormal (3-5). The etiology of this oliguria has been the subject of considerable discussion and has naturally focused attention on the functional capacity of the kidney in patients with severe liver disease. The evaluation of kidney function in patients with cirrhosis of the liver is complicated by the fact that the disease has widespread physiological effects, and single renal clearance tests are subject to many variables such as the degree of ascites, the serum level of proteins, sodium and chloride, the extent of the liver damage, the degree of anemia, the increase in blood volume and the nutritional state of the patient.

In the studies reported in this paper, renal clearances were determined on patients with cirrhosis of the liver at different stages of the disease. In several patients it was possible to repeat the clearances during the period of rapid reaccumulation of ascitic fluid and again at the time when control of ascites, as a result of therapy, had occurred. As the control of ascites is invariably associated with re-establishment of diuresis in the patient, it is of considerable interest to follow the renal clearances during the course of the disease.

\section{PROCEDURES}

A total of 32 clearances has been measured in 17 patients who were grouped as follows: Group 1 consisted of six patients in whom ascites was never present or was not present to a degree requiring paracentesis; 11 renal clearances were determined in this group. Group 2 con-

1 This research was aided by a grant from The United States Public Health Service. sisted of six patients who had all required paracenteses during the course of therapy but at the time of the clearance studies, as a result of therapy no longer had ascites to a sufficient degree to require further taps; 10 renal clearances were measured in this group. Group 3 consisted of seven patients in whom ascitic fluid was rapidly reaccumulating, requiring taps at intervals of from seven to 16 days; a total of 11 clearances was determined in these patients. In this latter group most of the clearances were determined on the patients one or two days following paracentesis in order to avoid the factor of increased intra-abdominal pressure. However, clearances were also measured in several patients at varying intervals after the taps in order to evaluate the effect of the intra-abdominal pressure due to accumulated ascitic fluid. In two patients the clearances were determined from the onset of therapy and were repeated during the course of the disease until ascites had been controlled. In seven subjects the clearances were repeated more than once.

\section{METHODS}

Glomerular filtration rate was measured by the inulin clearance, and renal plasma flow by the p-aminohippurate clearance (6). ${ }^{2}$ The procedures employed were those described by Goldring and Chasis (7). Inulin was determined by Harrison's modification of the diphenylamine method (8); p-aminohippurate was determined by the method of Finkelstein, Aliminosa, and Smith (9). All urine samples were collected by means of an indwelling multi-eyed catheter. Serum protein was determined on the initial fasting blood by Howe's method (10), serum chloride by a modification of Sendroy's method (11); and serum sodium by the method of Butler and Tuthill as described by Peters and Van Slyke (12). Later, serum sodium was determined in the flame photometer with reference to a lithium standard.

\section{RESULTS}

Table $I$ is a summary of the data on the patients at the time of admission to the hospital. The diagnosis of cirrhosis of the liver was clearly established on the basis of physical examination

2 All values for glomerular filtration rate $\left(\mathrm{C}_{\mathrm{IN}}\right)$, effective renal plasma flow ( $\left.C_{P A B}\right)$ and maximal tubular excretion of $p$-aminohippurate $\left(\mathrm{Tm}_{\mathrm{PAB}}\right)$ reported are averages of three determinations. 
and laboratory data, and except for cases 8, 59 and 73, was confirmed by liver biopsies.

The oliguria that occurs in patients with cirrhosis of the liver is well known. In Figure 1 are charted the 24 hour urine volumes of a 49 year old white male, for a period of 52 days. The urine output and its relation to the accumulation of ascitic fluid is demonstrated.

Further evidence of the diminished urine output in the patients was demonstrated by the water tolerance tests. Eight of the patients in the present group were given $1,500 \mathrm{cc}$. of water by mouth and the urine collected by catheter at 30 minute intervals for a period of 240 minutes. The time required for the excretion of 50 per cent of the ingested water was definitely prolonged. The average time was 160 minutes as compared to 92 minutes for normal subjects. The extent of the depression in the water tolerance test, as has been reported previously (5), was related to the severity of the disease.

Renal clearances in the patients in whom ascites was not severe enough to require paracentesis, or in whom ascites could not be detected clinically (Group 1), are given in Table II. Eleven clearances were measured on the six male patients in this group. None of the clearances were de-
TABLE I

Data on patients at time of admission

\begin{tabular}{|c|c|c|c|c|c|c|c|}
\hline \multirow{2}{*}{$\begin{array}{l}\text { Case } \\
\text { No. }\end{array}$} & \multirow{2}{*}{$\begin{array}{c}\text { Age } \\
\text { (yrs.) }\end{array}$} & \multirow{2}{*}{ Sex } & \multirow{2}{*}{ Ascites } & \multirow{2}{*}{$\begin{array}{c}\text { Total } \\
\text { no. of } \\
\text { para- } \\
\text { centeses }\end{array}$} & \multicolumn{3}{|c|}{ Serum proteins } \\
\hline & & & & & $\underset{\text { (sm. \%) }}{\text { Total }}$ & $\underset{\text { (gm. \%) }}{\text { Albumin }}$ & $\underset{(\mathrm{gm} . \%)}{\text { Globulin }}$ \\
\hline $\begin{array}{r}1 \\
8 \\
23 \\
28 \\
48 \\
59 \\
70 \\
71 \\
72 \\
73 \\
74 \\
75 \\
76 \\
77 \\
78 \\
79 \\
80\end{array}$ & $\begin{array}{l}49 \\
53 \\
42 \\
46 \\
42 \\
47 \\
59 \\
45 \\
68 \\
58 \\
45 \\
35 \\
64 \\
54 \\
55 \\
58 \\
50\end{array}$ & $\begin{array}{l}\mathbf{M} \\
\mathbf{M} \\
\mathbf{M} \\
\mathbf{M} \\
\mathbf{M} \\
\mathbf{F} \\
\mathbf{M} \\
\mathbf{M} \\
\mathbf{M} \\
\mathbf{M} \\
\mathbf{M} \\
\mathbf{F} \\
\mathbf{M} \\
\mathbf{M} \\
\mathbf{M} \\
\mathbf{M} \\
\mathbf{M}\end{array}$ & $\begin{array}{l}\mathbf{Y} \\
\mathbf{N} \\
\mathbf{Y} \\
\mathbf{Y} \\
\mathbf{N} \\
\mathbf{Y} \\
\mathbf{Y} \\
\mathbf{Y} \\
\mathbf{Y} \\
\mathbf{N} \\
\mathbf{N} \\
\mathbf{Y} \\
\mathbf{Y} \\
\mathbf{Y} \\
\mathbf{Y} \\
\mathbf{Y} \\
\mathbf{Y}\end{array}$ & $\begin{array}{r}8 \\
0 \\
0 \\
14 \\
0 \\
22 \\
0 \\
2 \\
12 \\
0 \\
0 \\
8 \\
20 \\
6 \\
2 \\
0 \\
1\end{array}$ & $\begin{array}{l}6.5 \\
6.4 \\
7.5 \\
5.0 \\
8.1 \\
5.7 \\
5.2 \\
6.4 \\
6.1 \\
6.7 \\
6.7 \\
6.0 \\
5.4 \\
6.2 \\
8.0 \\
7.0\end{array}$ & $\begin{array}{l}2.5 \\
3.8 \\
2.7 \\
2.5 \\
2.7 \\
2.8 \\
2.0 \\
2.4 \\
2.1 \\
4.8 \\
2.7 \\
2.5 \\
2.0 \\
2.6 \\
3.1 \\
2.8\end{array}$ & $\begin{array}{l}4.0 \\
2.6 \\
4.8 \\
2.5 \\
5.4 \\
2.9 \\
3.2 \\
4.0 \\
4.0 \\
1.9 \\
4.0 \\
3.5 \\
3.4 \\
3.6 \\
4.9 \\
4.2 \\
-\end{array}$ \\
\hline
\end{tabular}

pressed. In three subjects (Cases $23,73,79$ ) the filtration rates were $55 \mathrm{cc} . / \mathrm{min}$. to $252 \mathrm{cc} . / \mathrm{min}$. above the mean normal. In one of these patients the serum albumin level was low (2.8 gm. per cent), in the other two it was normal. The $\mathrm{C}_{\mathbf{P} \Delta \mathrm{B}}$ was elevated in two subjects (Cases 48,73 ) above the mean normal value for males by 276 to 792 cc./min. and depressed in the initial clearance in

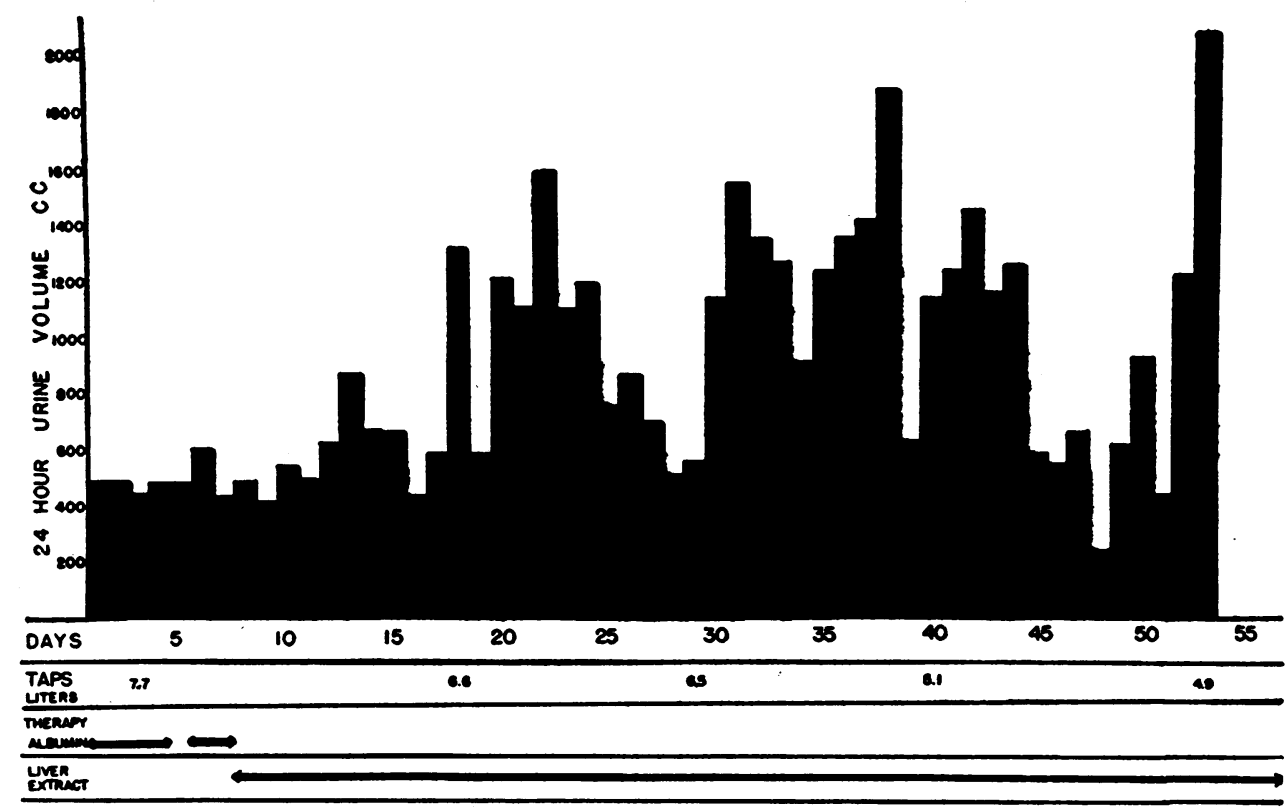

Fig. 1. Twenty-four Hour Urine Volumes in Male Subject with Cirrhosis of the LIVER AND Ascites

Days of observation and amount of fluid removed at paracenteses are indicated. 
TABLE II

Renal clearances in patients with cirrhosis of the liver (Group I)

Ascites never present or not present to a degree that required paracentesis

\begin{tabular}{|c|c|c|c|c|c|c|c|c|c|c|c|c|c|c|c|c|}
\hline \multirow{2}{*}{$\begin{array}{l}\text { Case } \\
\text { No. }\end{array}$} & \multirow{2}{*}{ 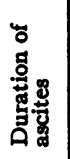 } & \multirow{2}{*}{ 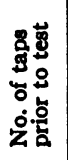 } & \multirow{2}{*}{ 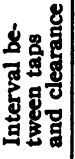 } & \multicolumn{2}{|c|}{ Plasma clearance } & \multirow{2}{*}{$\begin{array}{l}\text { Effec- } \\
\text { tive } \\
\text { renal } \\
\text { blood } \\
\text { flow }\end{array}$} & \multirow{2}{*}{ TmPaA } & \multirow{2}{*}{$\begin{array}{l}\text { Filtra- } \\
\text { tion } \\
\text { frac- } \\
\text { tion }\end{array}$} & \multirow{2}{*}{$\frac{\text { CPAR }_{\text {PAP }}}{\text { TmPAB }_{\text {PA }}}$} & \multirow{2}{*}{$\frac{C_{\text {IN }}}{\text { TmPAB }_{\text {PA }}}$} & \multirow{2}{*}{ 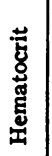 } & \multicolumn{3}{|c|}{ Serum proteins } & \multicolumn{2}{|c|}{ Serum } \\
\hline & & & & Inulin & PAH & & & & & & & Total & $\underset{\text { min }}{\text { Albu- }}$ & $\underset{\text { lin }}{\text { Globu- }}$ & $\mathrm{Na}$ & $\mathrm{Cl}$ \\
\hline $\begin{array}{r}23 \\
23 \\
8 \\
8 \\
48 \\
48 \\
73 \\
73 \\
79 \\
74 \\
74\end{array}$ & $\begin{array}{c}\text { (woks.) } \\
7 \\
7 \\
1 \\
1 \\
0 \\
0 \\
0 \\
0 \\
2 \\
3 \\
3\end{array}$ & $\begin{array}{l}0 \\
0 \\
0 \\
0 \\
0 \\
0 \\
0 \\
0 \\
0 \\
0 \\
0\end{array}$ & 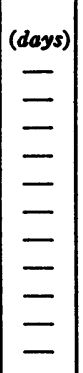 & $\begin{array}{l}(c c . l \\
\text { min. }) \\
250 \\
179 \\
113 \\
144 \\
134 \\
134 \\
376 \\
286 \\
357 \\
126 \\
106\end{array}$ & $\begin{array}{c}(c c . l \\
\text { min. }) \\
443 \\
593 \\
540 \\
609 \\
945 \\
946 \\
1,451 \\
930 \\
838 \\
660 \\
869\end{array}$ & $\begin{array}{r}(c c . l \\
\text { mix. }) \\
852 \\
1,120 \\
914 \\
1,127 \\
1,817 \\
1,754 \\
2,738 \\
1,753 \\
1,230 \\
1,138 \\
1,500\end{array}$ & $\begin{array}{c}\text { (mg.l } \\
\text { min.) } \\
92 \\
54 \\
119 \\
77 \\
65 \\
71 \\
99 \\
99 \\
130 \\
\frac{1}{99}\end{array}$ & $\begin{array}{l}(\%) \\
56 \\
30 \\
21 \\
24 \\
14 \\
14 \\
26 \\
31 \\
43 \\
19 \\
12\end{array}$ & $\begin{array}{r}4.8 \\
11.0 \\
4.5 \\
7.9 \\
14.6 \\
13.3 \\
14.6 \\
9.4 \\
6.4 \\
8.8\end{array}$ & $\begin{array}{l}2.7 \\
3.3 \\
1.0 \\
1.9 \\
2.1 \\
1.9 \\
3.8 \\
2.9 \\
2.7 \\
\frac{1.0}{1.0}\end{array}$ & $\begin{array}{l}48 \\
47 \\
41 \\
46 \\
48 \\
46 \\
47 \\
47 \\
32 \\
42\end{array}$ & 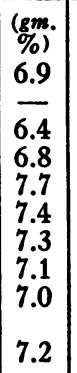 & $\begin{array}{c}(\mathrm{gm. \%}) \\
3.7 \\
3.8 \\
4.4 \\
4.4 \\
3.8 \\
5.5 \\
4.9 \\
2.8 \\
3.4\end{array}$ & $\begin{array}{c}(\mathrm{gm. \%}) \\
3.2 \\
2.6 \\
2.4 \\
3.3 \\
3.6 \\
1.8 \\
2.2 \\
4.2 \\
3.8\end{array}$ & \begin{tabular}{|c}
$($ meq/L. $)$ \\
129 \\
-137 \\
134 \\
138 \\
134 \\
141 \\
- \\
- \\
136
\end{tabular} & $\begin{array}{c}(\text { meq/L.) } \\
97 \\
-101 \\
100 \\
102 \\
101 \\
102 \\
- \\
- \\
100\end{array}$ \\
\hline \multicolumn{4}{|c|}{ Mean } & 200 & 802 & 1,449 & 91 & 26 & 9.5 & 2.3 & & & & & & \\
\hline & & $\begin{array}{l}C_{\text {IN }} \\
1 \pm\end{array}$ & 25.8 & & $\begin{array}{l}\text { CPAB } \\
\pm 163\end{array}$ & Mean & $\begin{array}{l}\text { of norm } \\
\text { TmPAH } \\
8 \pm 16 .\end{array}$ & 1 value & $\begin{array}{c}\text { s } \pm \text { S.D } \\
\begin{array}{c}\text { Filtrati } \\
\text { fractio }\end{array} \\
19.2 \pm\end{array}$ & (6). & & $\begin{array}{l}\text { CPAH } \\
\text { TmPAE } \\
4 \pm 2\end{array}$ & .45 & $\begin{array}{l}\frac{C}{\mathrm{Tm}} \\
1.6=\end{array}$ & $\begin{array}{l}\frac{\mathrm{CNN}}{\mathrm{APAB}} \\
\pm 0.44\end{array}$ & \\
\hline
\end{tabular}

one (Case 23) by $211 \mathrm{cc} / \mathrm{min}$. $T \mathrm{~m}_{\mathrm{PAB}}$ was 39.2 and $50.2 \mathrm{mg} . / \mathrm{min}$. above the mean normal in the initial clearances in Cases 8 and 79. The mean filtration rate of $200 \mathrm{cc}$. $/ \mathrm{min}$. for this group exceeds the average normal by $76 \mathrm{cc}$. $/ \mathrm{min}$. The mean renal plasma flow of $802 \mathrm{cc} . / \mathrm{min}$. and maximal tubular excretion of $91 \mathrm{mg} . / \mathrm{min}$. are both within the upper limits of the normal range.
The mean filtration fraction of 26 per cent exceeded the normal by 7 per cent, whereas $\mathrm{C}_{\mathrm{PAB}}$ / $\mathrm{Tm}_{\mathrm{PAB}}$ and $\mathrm{C}_{\mathrm{IN}} / \mathrm{Tm}_{\mathrm{PAB}}$ ratios of 9.5 and 2.3 respectively, are normal.

Table III gives the results of renal clearances determined in patients at a time when ascites was no longer present or was insufficient to require further paracentesis (Group II). Ten clearances

TABLE III

Renal clearances in patients with cirrhosis of the liver (Group II)

At time when ascites was not sufficient to require paracentesis (all had required repeated paracenteses previously)

\begin{tabular}{|c|c|c|c|c|c|c|c|c|c|c|c|c|c|c|c|c|}
\hline \multirow{2}{*}{$\begin{array}{l}\text { Case } \\
\text { No. }\end{array}$} & \multirow{2}{*}{ 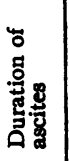 } & \multirow{2}{*}{ 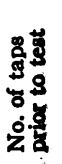 } & \multirow{2}{*}{ 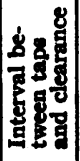 } & \multicolumn{2}{|c|}{ Plasma clearance } & \multirow{2}{*}{$\begin{array}{l}\text { Effec- } \\
\text { tive } \\
\text { renal } \\
\text { blood } \\
\text { flow }\end{array}$} & \multirow{2}{*}{ TmPAH } & \multirow{2}{*}{$\begin{array}{l}\text { Filtra- } \\
\text { tion } \\
\text { frac- } \\
\text { tion }\end{array}$} & \multirow{2}{*}{$\frac{C_{P A E}}{\operatorname{TmPAH}}$} & \multirow{2}{*}{$\frac{\mathrm{C}_{\mathrm{IN}}}{\operatorname{Tm}_{\mathrm{PAB}}}$} & \multirow{2}{*}{ 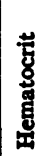 } & \multicolumn{3}{|c|}{ Serum proteins } & \multicolumn{2}{|c|}{ Serum } \\
\hline & & & & Inulin & PAH & & & & & & & Total & $\underset{\text { min }}{\text { Albu- }}$ & $\underset{\text { lin }}{\text { Globu- }}$ & $\mathrm{Na}$ & $\mathrm{Cl}$ \\
\hline $\begin{array}{r}28 \\
28 \\
28 \\
80 \\
77 \\
59 \\
76 \\
76 \\
1 \\
1\end{array}$ & $\begin{array}{c}\text { (wks.) } \\
49 \\
49 \\
49 \\
8 \\
14 \\
91 \\
49 \\
49 \\
38 \\
38\end{array}$ & $\begin{array}{r}14 \\
14 \\
14 \\
1 \\
6 \\
21 \\
17 \\
17 \\
8 \\
8\end{array}$ & \begin{tabular}{|r|}
$($ desss $)$ \\
255 \\
270 \\
343 \\
7 \\
7 \\
170 \\
42 \\
119 \\
224 \\
245
\end{tabular} & $\begin{array}{c}\text { (cc.l } \\
\text { min.) } \\
120 \\
128 \\
109 \\
172 \\
118 \\
70 \\
52 \\
120 \\
74 \\
74\end{array}$ & $\begin{array}{l}\left(c c_{1} l\right. \\
\text { mix.) } \\
621 \\
627 \\
592 \\
779 \\
583 \\
765 \\
465 \\
426 \\
340 \\
392\end{array}$ & $\begin{array}{r}\left(c_{.} /\right. \\
\text {mit.) } \\
1,150 \\
\cdot 1,140 \\
1,116 \\
1,175 \\
1,002 \\
1,160 \\
728 \\
615 \\
531 \\
622\end{array}$ & $\begin{array}{r}(m f) \\
(m 6) \\
66 \\
64 \\
66 \\
82 \\
70 \\
147 \\
73 \\
62 \\
54 \\
57\end{array}$ & $\begin{array}{r}(\%) \\
19 \\
20 \\
18 \\
22 \\
20 \\
9 \\
11 \\
28 \\
22 \\
19\end{array}$ & $\begin{array}{l}9.4 \\
9.8 \\
9.0 \\
9.5 \\
8.3 \\
5.2 \\
6.4 \\
6.9 \\
6.3 \\
6.9\end{array}$ & $\begin{array}{l}1.8 \\
2.0 \\
1.7 \\
2.1 \\
1.7 \\
0.5 \\
0.7 \\
1.9 \\
1.4 \\
1.3\end{array}$ & $\begin{array}{l}46 \\
45 \\
47 \\
32 \\
43 \\
34 \\
35 \\
42 \\
36 \\
37\end{array}$ & $\begin{array}{l}(\%) \\
6.3 \\
6.5 \\
6.6 \\
\\
6.6 \\
5.7 \\
7.0 \\
7.4 \\
7.1 \\
7.1\end{array}$ & $\begin{array}{c}\text { (som.\%) } \\
4.8 \\
4.0 \\
4.1 \\
3.9 \\
3.2 \\
2.7 \\
2.8 \\
3.3 \\
3.3\end{array}$ & $\begin{array}{c}(\mathrm{cm} . \%) \\
1.5 \\
2.5 \\
2.5 \\
\\
2.7 \\
2.5 \\
4.3 \\
4.6 \\
3.8 \\
3.8\end{array}$ & $\begin{array}{c}\text { (meq/L. }) \\
133 \\
135 \\
139\end{array}$ & $\begin{array}{c}\text { (meq/L.) } \\
104 \\
106 \\
100 \\
103 \\
94 \\
104 \\
- \\
106 \\
-\end{array}$ \\
\hline \multicolumn{4}{|c|}{ Mean } & 104 & 559 & 924 & 74 & 19 & 7.8 & 1.5 & & & & & & \\
\hline
\end{tabular}


were measured on six patients in this group. The filtration rates in two subjects (Cases 59 and 76) were $40 \mathrm{cc}$. and $72 \mathrm{cc} . / \mathrm{min}$. below the mean normal. Both patients were poorly nourished and had required 20 and 17 paracenteses, respectively, during the course of therapy. In Case 80, in whom a single paracentesis was performed seven days prior to the clearance determination and in whom no further reaccumulation of ascitic fluid had occurred, the filtration rate was $172 \mathrm{cc} . / \mathrm{min}$. Renal plasma flows were depressed in two patients (Cases 1 and 76) ranging from $189 \mathrm{cc} . / \mathrm{min}$. to $314 \mathrm{cc} . / \mathrm{min}$. below the mean normal. $\mathrm{Tm}_{\mathrm{PAH}}$ was within normal limits in all of the patients except Case 59 in whom it was $70 \mathrm{mg} . / \mathrm{min}$. above the mean measurement for normal females. The mean value of $\mathrm{C}_{\mathrm{IN}}$ of $104 \mathrm{cc} . / \mathrm{min}$. was within normal limits. The mean filtration fraction was 19 per cent whereas the $\mathrm{C}_{\mathrm{PAH}} / \mathrm{Tm}_{\mathrm{PAB}}$ and $\mathrm{C}_{\mathrm{IN}}$ / $T_{\mathrm{PAB}}$ ratios ( 7.8 and 1.5 respectively) were depressed.

Eleven renal function tests were determined on seven patients with cirrhosis at a time when ascites was rapidly reaccumulating (Group III), requiring repeated paracenteses. The results are given in Table IV. In contrast to the mean for $\mathrm{C}_{\mathrm{IN}}$ in normal subjects $(124.1 \pm 25.8)$, the values are reduced in all but Cases 71, 78 and 70. The $\mathrm{C}_{\mathbf{P A B}}$ was elevated in Case 70 (774 cc./min.), but was depressed in the other 10 subjects. The mean clearance values were depressed: $\mathrm{C}_{\text {IN }}$ was 78 $\mathrm{cc}$./min. and $\mathrm{C}_{\mathbf{P A B}}$ was $425 \mathrm{cc}$./min. The filtration fraction ranged from 13 per cent to 27 per cent and averaged 19 per cent, which is normal. $\mathrm{Tm}_{\mathrm{PAB}}$ in this group varied from 32 to $99 \mathrm{mg}$./ $\mathrm{min}$. and the mean value was $63 \mathrm{mg} . / \mathrm{min}$., which is low normal.

To evaluate the effect of increased intraabdominal pressure, clearances were measured on the same patient at varying intervals after paracenteses. In Case 59 (Table IV), measurements were made two, nine and six days after succeeding paracenteses which were done at six week intervals. $C_{I N}$ was decreased in all three measurements: $C_{I N}$ two days after paracentesis was $39 \mathrm{cc} . / \mathrm{min}$., six days after paracentesis was $57 \mathrm{cc} . / \mathrm{min}$. and nine days after paracentesis was $58 \mathrm{cc} . / \mathrm{min}$. $\mathrm{C}_{\mathbf{P A B}}$ did not increase at these varying intervals of time following paracenteses (468, 508 , and $436 \mathrm{cc} . / \mathrm{min}$., respectively). The concentrations of serum total protein, albumin, globulin, sodium and chloride at the time of each clearance study showed no appreciable changes. Another example is Case 76 (Table IV) who required frequent paracenteses. In this patient renal functional measurements were made one and nine days after paracenteses and also just prior to a paracentesis. $\mathrm{C}_{\mathrm{IN}}$ was $65,86,54 \mathrm{cc}$./ min., respectively, and $C_{P A H}$ was 507,608 and 558 cc./min., respectively. In both patients, as the

TABLE IV

Renal clearances in patients with cirrhosis of the liver (Group III)

At time when ascites was rapidly reaccumulating and required repeated paracenteses

\begin{tabular}{|c|c|c|c|c|c|c|c|c|c|c|c|c|c|c|c|c|}
\hline \multirow{2}{*}{$\begin{array}{l}\text { Case } \\
\text { No. }\end{array}$} & \multirow{2}{*}{ 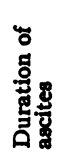 } & \multirow{2}{*}{ 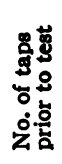 } & \multirow{2}{*}{ 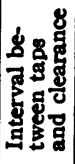 } & \multicolumn{2}{|c|}{ Plasma clearance } & \multirow{2}{*}{$\begin{array}{c}\text { Effec- } \\
\text { tive } \\
\text { renal } \\
\text { blood } \\
\text { flow }\end{array}$} & \multirow{2}{*}{$\operatorname{Tm}_{\mathbf{P A B}}$} & \multirow{2}{*}{$\begin{array}{l}\text { Filtra- } \\
\text { tion } \\
\text { frac- } \\
\text { tion }\end{array}$} & \multirow{2}{*}{$\frac{C_{\text {PAH }}}{\text { TmPAH }}$} & \multirow{2}{*}{$\frac{\mathrm{C}_{\mathrm{nN}}}{\operatorname{TmPAB}_{\mathrm{PA}}}$} & \multirow{2}{*}{ 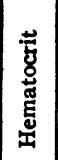 } & \multicolumn{3}{|c|}{ Serum proteins } & \multicolumn{2}{|c|}{ Serum } \\
\hline & & & & Inulin & PAH & & & & & & & Total & $\underset{\text { min }}{\text { Albu- }}$ & $\underset{\text { lin }}{\text { Globu- }}$ & $\mathrm{Na}$ & $\mathrm{Cl}$ \\
\hline $\begin{array}{l}75 \\
59 \\
59 \\
59 \\
72 \\
71 \\
78 \\
70 \\
76 \\
76 \\
76\end{array}$ & $\begin{array}{c}\text { (wks.) } \\
25 \\
28 \\
34 \\
41 \\
42 \\
8 \\
- \\
-22 \\
24 \\
29\end{array}$ & $\begin{array}{r}8 \\
14 \\
15 \\
16 \\
12 \\
2 \\
2 \\
10 \\
4 \\
7 \\
15\end{array}$ & \begin{tabular}{|c|}
$($ days $)$ \\
2 \\
2 \\
9 \\
6 \\
8 \\
1 \\
1 \\
1 \\
9 \\
1 \\
0
\end{tabular} & $\begin{array}{c}(c c . / \\
\min .) \\
68 \\
39 \\
58 \\
57 \\
68 \\
106 \\
153 \\
100 \\
86 \\
65 \\
54\end{array}$ & $\begin{array}{l}(c c . l \\
\text { min. } \\
515 \\
309 \\
253 \\
330 \\
466 \\
440 \\
594 \\
774 \\
322 \\
315 \\
357\end{array}$ & $\begin{array}{c}(c c . l \\
\text { min.) } \\
758 \\
468 \\
436 \\
508 \\
818 \\
746 \\
\overline{1,380} \\
608 \\
507 \\
558\end{array}$ & $\begin{array}{c}\left(\begin{array}{c}(m g . / \\
\text { min. }\end{array}\right. \\
60 \\
32 \\
35 \\
54 \\
99 \\
70 \\
93 \\
58 \\
58 \\
74\end{array}$ & $\begin{array}{l}(\%) \\
13 \\
13 \\
23 \\
17 \\
15 \\
24 \\
26 \\
13 \\
27 \\
21 \\
15\end{array}$ & $\begin{array}{r}8.6 \\
9.7 \\
r .1 \\
9.2 \\
8.6 \\
4.4 \\
8.5 \\
8.3 \\
5.6 \\
5.4 \\
4.8\end{array}$ & $\begin{array}{l}1.1 \\
1.2 \\
1.6 \\
1.3 \\
1.1 \\
2.2 \\
1.1 \\
1.5 \\
1.1 \\
0.7\end{array}$ & $\begin{array}{l}32 \\
34 \\
42 \\
35 \\
43 \\
41 \\
44 \\
47 \\
38 \\
36\end{array}$ & $\begin{array}{l}\text { (gm. } \\
\%) \\
6.0 \\
5.7 \\
5.7 \\
5.7 \\
6.6 \\
6.4 \\
8.0 \\
5.5 \\
5.4 \\
5.9\end{array}$ & $\begin{array}{c}(\mathrm{gm. \%}) \\
2.5 \\
2.8 \\
2.5 \\
2.4 \\
2.3 \\
2.4 \\
3.1 \\
2.2 \\
2.0 \\
\overline{1.9}\end{array}$ & \begin{tabular}{|c|}
$(\mathrm{gm} . \%)$ \\
3.5 \\
2.9 \\
3.2 \\
3.3 \\
4.3 \\
4.0 \\
4.9 \\
3.2 \\
3.5 \\
4.0
\end{tabular} & $\begin{array}{c}\text { (meq/L.) } \\
\overline{135} \\
140 \\
138 \\
131 \\
129 \\
132 \\
\overline{124} \\
\frac{135}{135}\end{array}$ & $\begin{array}{c}\text { (meq/L.) } \\
\overline{102} \\
106 \\
104 \\
105 \\
97 \\
96 \\
\frac{102}{103} \\
\overline{103}\end{array}$ \\
\hline \multicolumn{4}{|c|}{ Mean } & 78 & 425 & 679 & 63 & 19 & 7.3 & 1.3 & & & & & & \\
\hline
\end{tabular}


abdomen became distended with the reaccumulated ascitic fluid, the filtration fraction increased.

The results of repeated renal functional measurements during the course of the disease are illustrated in Figures 2 and 3 . Four clearances were measured in Case 59 during a 66 week period, three during the period of rapid reaccumulation of ascitic fluid (16 taps were done during this period) and one clearance six months after the last tap, at which time paracenteses were no longer required. In Case 76, five clearances were determined over a period of 10 months, three of these during the time when ascitic fluid was accumulating. The fourth clearance was measured at the time ascites was beginning to disappear, and no paracenteses had been required for 42 days. The fifth clearance was done when ascites was controlled, and an interval of 180 days had elapsed since the previous paracentesis. In both patients, during the period of rapid fluid reaccumulation, renal function was depressed. If one compares the results in these two cases to the averages of the groups of patients shown in Tables III and IV, the clearances determined when ascites was severe are comparable to those in the patients in Group III. In Case 59, the clearance values six months after the last paracentesis are in the range of the patients in Group II, although in this particular patient $\mathrm{Tm}_{\mathbf{P A H}}$ is slightly higher than the average for the group. In Case

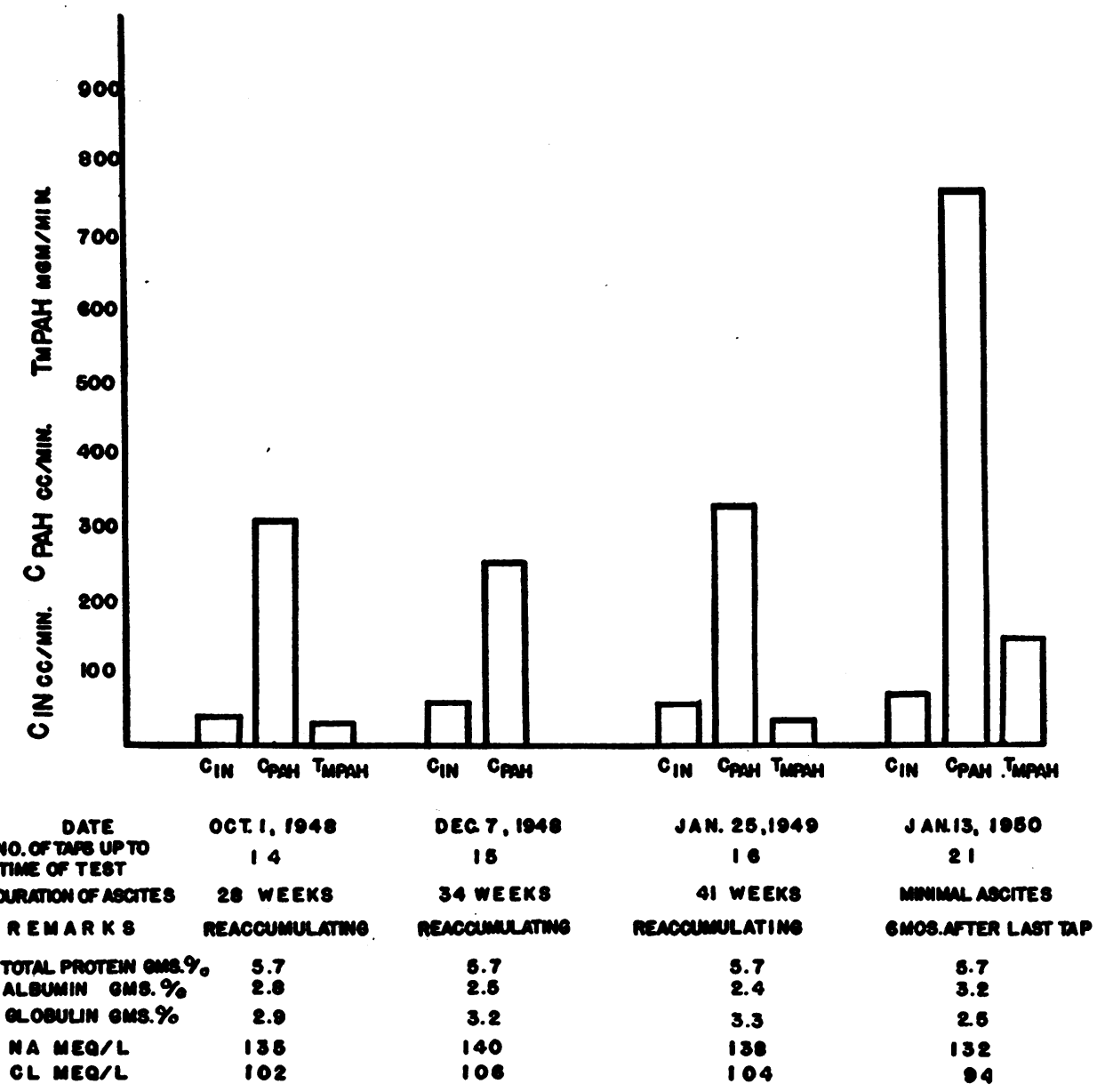

Fig. 2. Case No. 59. Repeated Renal Clearances in a Female Patient with Cirrhosis of the Liver During Periods of Severe Ascites Requiring Repeated Paracenteses, and at a Trme When Ascites was Controlled

The number of paracenteses, serum constituents and duration of ascites are indicated at the time of each clearance measurement. 


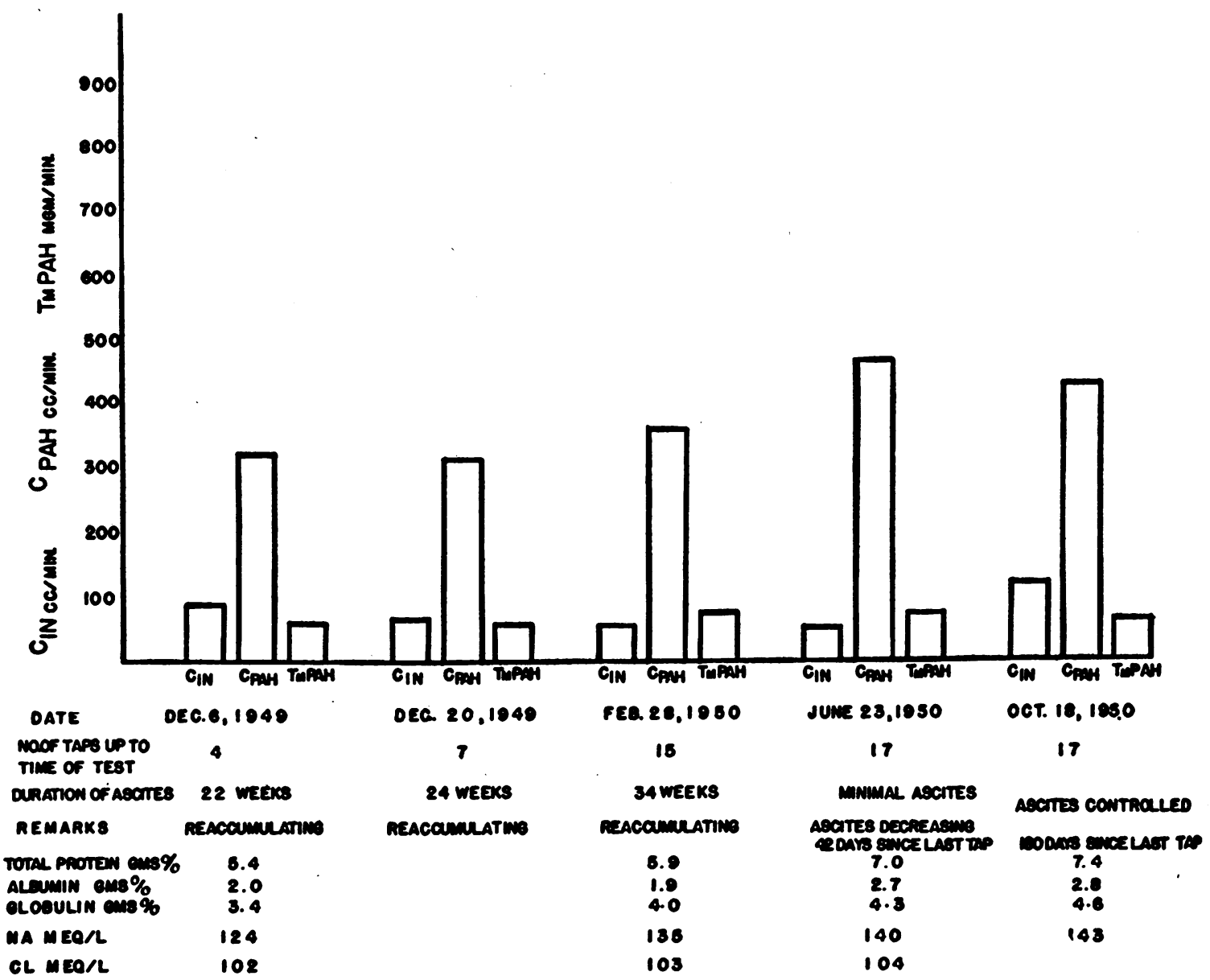

Fig. 3. Case No. 76. Repeated Renal Clearances in a Male Patient with Cirrhosis of the Liver During the Course of the Disease

Number of paracenteses, serum constituents and duration of ascites are indicated at the time of each clearance measurement.

76 the clearances 180 days after the last paracentesis are also in the range of Group II. The observations on these two patients during periods of severe ascites and at a time when ascites was controlled indicate that renal function improves once ascites is controlled.

\section{DISCUSSION}

The interpretation of renal functional measurements in patients with cirrhosis of the liver is difficult, owing to the widespread physiological effects of the disease. The clearance techniques used in the studies provide quantitative information on the renal plasma flow, glomerular filtration rate and maximal tubular excretory capacity. Total renal flow, utilizing $\mathrm{E}_{\mathrm{PAB}}$, was not deter- mined as there was no evidence of extensive renal pathology. In the determinations of $\mathrm{C}_{\mathbf{P A B}}$, the plasma levels of $p$-aminohippurate only exceeded $4 \mathrm{mg}$. per cent in three subjects (Cases 59, 71 and 77) and in these cases were, respectively, 5.9, 6.4 and 6.3 per cent. It is therefore reasonable to assume that almost all of the p-aminohippurate perfusing the kidneys was removed (13).

Renal clearances in the patients with rapidly reaccumulating ascites requiring repeated paracenteses were all decreased (Group III). The filtration fraction was normal. The low $\mathrm{C}_{\mathbf{P A B}} /$ $\mathrm{Tm}_{\mathbf{P A B}}$ indicates a diminished perfusion of the kidney with relative ischemia of the functional tubules, and the low $\mathrm{C}_{\mathrm{IN}} / \mathrm{Tm}_{\mathrm{PAB}}$ ratio indicates hypofiltration in the active nephrons. Obviously 
at the stage of the disease when ascites is marked, the retention of sodium and water is undoubtedly due to more than one factor, and not solely to the influence that the antidiuretic hormone exerts on the tubular reabsorption of water. The decreased filtration rate is a factor reducing the quantity of sodium delivered to the tubules (14), and may also lead to the retention of sodium and water during this phase of cirrhosis.

The renal functional measurements in Group II indicate that once ascites is controlled, the $\mathrm{C}_{\mathrm{IN}}, \mathrm{C}_{\mathrm{PAB}}$ and $\mathrm{Tm}_{\mathrm{PAB}}$ tend to improve. As reported previously (5) these changes are also associated with an improvement in the water tolerance test. These combined observations support the thesis that diuresis is related to restoration of kidney function in patients with liver disease. In the patients in Group II, the $\mathrm{C}_{\mathrm{PAB}} / \mathrm{Tm}_{\mathrm{PAB}}$ and $\mathrm{C}_{\mathrm{IN}} / \mathrm{Tm}_{\mathrm{P} \Delta \mathrm{H}}$ ratios were normal and the average plasma filtration fraction remained normal. Thus the factors of persistent relative ischemia of the active tubules, diminished filtration in the active nephrons, and decreased glomerular filtration rate were apparently no longer operating during this phase of the disease.

The clearances in patients who never had had ascites or in whom ascites had never required paracentesis (Group I) were either elevated or were in the upper range of normal. The average filtration fraction of 26 per cent was the result of an elevated filtration rate. Perfusion of the kidneys was normal at this stage as indicated by the $\mathrm{C}_{\mathrm{PAB}} / \mathrm{Tm}_{\mathrm{PAH}}$ of $9.5 \mathrm{cc} . / \mathrm{mg}$. (normal $=8.44 \pm$ $2.45 \mathrm{cc} . / \mathrm{mg}$.). There was definite evidence of hyperfiltration in the active nephrons shown by the $\mathrm{C}_{\mathrm{IN}} / \mathrm{Tm}_{\mathrm{PAB}}$ ratio of $2.3 \mathrm{cc} . / \mathrm{mg}$. (normal = $1.64 \pm 0.44 \mathrm{cc} . / \mathrm{mg}$.). The water tolerance tests (5) in these patients at this time were normal, indicating that renal function is not altered in the early stages of cirrhosis when the serum protein levels have not been seriously disturbed, and at a time when extensive liver damage has probably not taken place.

The repeated clearances done in patients 59 and 76 (Figures 2 and 3) illustrate the improvement in renal function occurring as a result of therapy. During ascitic fluid accumulation renal function was reduced; when renal function improved, reaccumulation of ascitic fluid decreased. In these studies, the amount of ascitic fluid present in the abdomen did not significantly effect, one way or the other, the already decreased clearances. This is in contrast to the results of Bradley and Bradley (15) on the effects of the application of a pneumatic belt in normal subjects. The abdominal pressure induced by their procedure was associated with a reduction of $\mathrm{C}_{\mathrm{PAB}}, \mathrm{C}_{\mathrm{IN}}$ and $\mathrm{Tm}_{\mathrm{PAH}}$.

Apparently the functional disturbance of the kidney observed in patients with cirrhosis of the liver and ascites is a reversible one and improves if the disease and the associated reaccumulation of ascitic fluid is controlled as a result of therapy.

\section{SUMMARY}

Thirty-two renal functional measurements were performed on 17 patients with cirrhosis of the liver at different stages of the disease. Filtration rate, effective renal plasma flow and $T \mathrm{~m}_{\mathbf{P} \mathbf{}}$ were reduced during the phase of ascitic fluid accumulation. With the cessation of need for further paracenteses, renal function was normal or even in the upper range of normal and was associated with an increased filtration fraction.

The observations lend support to the thesis that an important factor in inducing diuresis is the re-establishment of normal kidney function, which results in the physiological control of ascites.

\section{REFERENCES}

1. Gilbert, A., and Lereboillet, P., Des urines retardées (opsiurie) dans les cirrhoses. Compt. rend. Soc. de biol., 1901, 11, Series 3, 276.

2. Pick, E. P., The regulation of water metabolism. Harvey Lectures, 1929-30, Series XXV, p. 25.

3. Adlersberg, D., and Fox, C. L., Jr., Changes of the water tolerance tests in hepatic disease. Ann. Int. Med., 1943, 19, 624.

4. Labby, D. H., and Hoagland, C. L., Water storage and the movements of body fluids and chlorides during acute liver disease. J. Clin. Invest., 1947, 26, 343.

5. Ralli, E. P., Leslie, S. H., Stueck, G. H., Jr., and Laken, B., Studies of the serum and urine constituents in patients with cirrhosis of the liver during water tolerance tests. Am. J. Med., in press.

6. Smith, H. W., The Kidney. Oxford University Press, New York, 1951.

7. Goldring, W., and Chasis, H., Hypertension and Hypertensive Disease. The Commonwealth Fund, 1944, New York, N. Y., Appendix, D, p. 195.

8. Harrison, H. E., A modification of the diphenylamine method for the determination of inulin. Proc. Soc. Exper. Biol. \& Med., 1942, 49, 111. 
9. Finkelstein, N., Aliminosa, L., and Smith, H. W., The renal clearances of hippuric acid and pyridone derivatives. Am. J. Physiol., 1941, 133, 276.

10. Howe, P. E., The determination of proteins in the blood-a micro method. J. Biol. Chem., 1921, 49, 109.

11. Van Slyke, D. D., and Hiller, A., Application of Sendroy's iodometric chloride titration to proteincontaining fluids. J. Biol. Chem., 1947, 167, 107.

12. Peters, J. P., and Van Slyke, D. D., Quantitative Clinical Chemistry. II. Methods. The Williams and Wilkins Co., Baltimore, 1932, 732.
13. Merrill, A. J., and Cargill, W. H., The effect of exercise on the renal plasma flow and filtration rate of normal and cardiac subjects. J. Clin. Invest., 1948, 27, 272.

14. Bradley, S. E., The validity of the clearance technique in the measurement of renal blood flow in normal man and in patients with essential hypertension. The Josiah Macy, Jr. Foundation Conference on Factors Regulating Blood Pressure, 1947, 1, 118.

15. Bradley, S. E., and Bradley, G. P., The effect of increased intra-abdominal pressure on renal function in man. J. Clin. Invest., 1947, 26, 1010. 